\title{
PENINGKATAN PRESTASI BELAJAR SOSIOLOGI MATERI PERMASALAH SOSIAL MENGGUNAKAN METODE PROBLEM SOLVING DENGAN BERBANTUAN APLIKASI GAME EDUKATIF QUIZZIZ
}

\author{
Oleh: \\ Lia Prastyawati ${ }^{1}$
}

\begin{abstract}
Abstrak
Pembelajaran jarak jauh (PJJ) dimasa pandemi covid-19 ternyata menimbulkan beberapa permasalahan, diantaranya adalah menurunnya prestasi akademik peserta didik dalam mata pelajaran sosiologi. Penelitian tindakan kelas ini bertujuan untuk meningkatkan prestasi belajar sosiologi pada materi pemasalahan sosial kelas XI IPS jenjang SMA dengan menggunakan metode problem solving berbantuan quizziz. Penelitian ini dilaksanakan dalam pembelajaran jarak jauh moda daring di masa pandemi covid-19. Pembelajaran moda daring menggunakan platform googleclassroom, whatsaapgroup, googlemeet dan quizziz. Metode problem solving mengarahkan peserta didik untuk aktif, kolaboratif, komunikatif dan kritis dalam menentukan alternatif penyelesaian suatu masalah. Responden penelitian berjumlah 35 peserta didik kelas XI IPS SMA N 7 Purworejo. Data yang diperoleh dianalisis dengan teknik deskriptif kuantitatif. Hasil penelitian penerapan metode problem solving berbantuan quizziz dalam pembelajaran sosiologi menunjukkan peningkatan dalam aktivitas peserta didik dan perubahan prestasi yang positif dibuktikan dengan meningkatnya hasil belajar peserta didik dari prasiklus sampai siklus III. Dengan Kriteria Ketuntasan Minimal (KKM) sebesar 70. Pratindakan diperoleh rata-rata kelas 65 dengan 57\% peserta didik belum tuntas KKM dan 43\% peserta didik telah tuntas KKM. Siklus I rata-rata kelas meningkat menjadi 81 dengan capaian 6\% peserta didik belum tuntas KKM dan 94\% peserta didik telah tuntas KKM. Siklus II rata-rata kelas mengalami peningkatan menjadi 92 dengan capaian $100 \%$ peserta didik telah tuntas KKM. Penerapan metode problem solving berbantuan quizziz dalam prasiklus, siklus I dan siklus II mampu menaikkan prestasi belajar sosiologi, peningkatannya adalah 27 poin dengan presentasi peserta didik yang tuntas KKM adalah 100\%.
\end{abstract}

Kata Kunci: problem solving, prestasi belajar, quizziz

\footnotetext{
${ }^{1}$ Guru Sosiologi, SMA Negeri 7 Purworejo, email: liaprastyawati88@gmail.com
} 


\section{PENDAHULUAN}

Pandemi Covid-19 memberikan dampak yang sangat signifikan pada dunia pendidikan. Salah satunya adalah sistem pembelajaran tatap muka diganti dengan pembelajaran jarak jauh (PJJ). Aternatif PJJ yang dilaksanakan mayoritas adalah moda daring yang memanfaatkan tenologi. Penyelenggaraan pembelajaran jarak jauh dengan basic online mendorong guru dan peserta didik untuk meningkatkan pengetahuan dan keterampilan dalam bidang teknologi informasi dan. SMA Negeri 7 Purworejo salah satu penyelenggara PJJ moda daring. Pada awal pandemi, model daring yang dipakai menggunakan Whatsapp Group, karena dipandang paling mudah. Namun seiring waktu banyak permasalahan yang muncul salah satunya adalah storage handphone yang penuh dan handphone error. Memasukai tahun pelajaran baru, SMA N 7 Purworejo melakukan assesmen nonkognitif dan kognitif. Sehingga keluarkan kebijakan bahwa SMA N 7 Purworejo menyeragamkan platform dalam penyelenggaran PJJ yaitu dengan menggunakan googleclasroom. Pelatihan googleclassrom juga dilaksanakan sebelum tahun pelajaran baru 2020/2021.
Setelah dilaksanakan ternyata muncul beberapa permaaslahan diantaranya adalah menurunnya prestasi belajar peserta didik, keaktifan peserta didik dan kedisiplinan peserta didik dalam mengikuti PJJ. Hal serupa juga terjadi mata pelajaran sosiologi. Dari fakta-fakta di atas guru perlu membuat upaya untuk mengatasi permasalahan tersebut agar peserta didik tetap memiliki hasil belajar yang maksimal pada masa pembelajaran PJJ moda daring. Salah satu upaya yang dilakukan adalah dengan pennggunaan metode belajar problem solving dengan berbantuan aplikasi game edukatif quizziz. Tulisan ini merupakan bagian dari hasil penelitian dan usaha mengatasi permasalahan dalam meningkatkan prestasi belajar siswa kelas XI IPS SMA N 7 Purworejo khususnya mata pelajaran sosiologi materi permasalahan sosial dalam masyarakat.

Pendidikan jarak jauh (PJJ) adalah mengajarkan perserta didik belajar terpisah dari pendidik dan pembelajarannya menggunakan sumber belajar internet dan online sesuai teknologi informasi dan komunikasi dan dengan bantuan media yang canggih. Menurut pendapat Keegan yang dijelaskan Warsito (2007: No. 20: 941) karakteristik pendidikan jarak jauh 
adalah pembelajaran yang dikelola oleh suatu lembaga pendidikan yang dalam prosesnya posisi pengajar dan antara peserta didik terpisah satu dengan yang lain. Pembelajaran biasanya menggunakan teknologi komunikasi dua arah untuk berbagai informasi dan komunikasi mekanis sebagai bahan belajar. Pembelajaran jarak jauh biasanya menggunankan aplikasi e-learning yang disebut learning sistem managermen (LMS). Saat ini aplikasinya sudah sangat beragam mulai dari edmodo, moodle, googleclasroom, microsoft365 dan lain sebagainya.

Dari assesment kognitif dan nonkognitif yang telah dilaksanakan sebelumnya, SMA N 7 Purworejo menentukan platform googleclassrom sebagai satu-satunya media yang digunakan dalam pembelajaran jarak-jauh di era pandemi covid-19. Kelebihan googleclassroom adalah mobile friendly, yang berarti dapat di akses peserta didik yang tidak mempunyai laptop atau komputer, hanya dengan bermodal handphone berbasis android. Peserta didik dapat mengakses googleclassroom dimana saja dan kapan saja.Menu yang disediakan classroom juga mudah dikelola dan mudah dipahami bagi pemula. Vitur-vitur yang disediakan classroom juga dikondisikan sebagaimana serupa dengan kelas, seperti penugasan tenggat waktu, dihubungkan dengan googlemeet, serta pembelajaran dapat dijadwalkan diwaktu sebelum kelas dimulai. Kelebihan classroom lain adalah file dalam bentuk mp4, mp3, doc, pdf, zip dan masih banyak lagi otomatis masuk ke akun google drive. Google classroom juga otomatis mensinkronkan antara akun gmail dengan akun googleclass yang telah digunakan. Tanpa disadari pendidikan dimasa pandemi telah mengintegrasikan TPACK dalam proses pembelajarannya. Jurnal penelitian dari Mishra dan Koehler (2006) dengan judul Technological Pedagogical Content Knowledge: A framework for Teacher Knowledge, sampai saat ini telah menjadi acuan oleh banyak peneliti dan praktisi pendidikan dalam upaya mengembangkan beberapa model pembelajaran. Istilah yang kemudian dikenal dengan TPACK (Technological, Pedagogical, Content Knowledge) adalah sebuah framework (kerangka kerja) dalam mendesain model pembelajaran baru dengan 
menggabungkan tiga aspek utama yaitu teknologi, pedagogi dan konten/materi pengetahuan (ontologis). Teknologi adalah alternatif solusi pembelajaran di masa pandemi. Guru harus mendesain pembelajaran bermakna dan inovatif. Penggunaan media beruap handpone, googleclassroom, e-modul, video edukasi di youtube, quizziz dan LKPD online merupakan wujud nyata pengintegrasian TPACK dalam proses pembelajaran.

Tujuan penelitian ini adalah untuk meningkatkan hasil belajar sosiologi materi permasalahan sosial pada peserta didik kelas XI IPS 2 Tahun pelajaran 2020/2021. Manfaat dari penelitian ini antara lain adalah meningkatkan ketertarikan peserta didik untuk mengikuti proses pembelajaran sosiologi di kelas pembelajaran jarak jauh, meningkatkan kualitas peserta didik dalam mata pelajaran sosiologi, memberikan suasana yang menyenangkan dalam proses pembelajaran dengan digunakannya metode problem solving dengan berbantuan aplikasi game edukatif quizziz dan meningkatkan hasil belajar peserta didik dengan diterapkannya metode problem solving dengan berbantuan aplikasi game edukatif quizziz.

\section{METODE PENELITIAN}

Penelitian ini merupakan Penelitian Tindakan Kelas (PTK). Desain penelitian tindakan kelas yang digunakan adalah model tindakan kelas spiral yang dikembangkan oleh Kemmis dan Mc Taggart dalam Krisyanto, (2011). Pelaksanaan tindakan terdisi dari prasiklus, siklus I dan siklus II, yang mana siklus I terdisi dari 2 pertemuan dan siklus 3 terdiri dari 1 pertemuan. Adapun tahan dalam siklus I dan II adalah sebgai berikut: 1) Pembukaan 2) kegiatan inti (penerapan metode problem solving yang dipandu menggunakan lembar kerja peserta didik (LKPD) dan evaluasi menggunakan quizziz 3) Penutup.

Subjek penelitian adalah peserta didik kelas XI IPS SMAN 7 Purworejo 2020/2021. Sedangkan sampel kelas yang dipilih dan dikenai penelitian tindakan kelas adalah kelas XI IPS 2 yang berjumlah 35 peserta didik. Teknik pengumpulan data dalam penelitian ini adalah menggunakan tes dan dokumentasi. Sumber data yang digunakan adalah tindakan yang dilaksanakan pada prasiklus, siklus I dan siklus II. Intrumen yang digunakan dalam penelitian ini 
berupa intrumen tes dan non tes. Adapun intrumen yang digunakan antara lain: 1) instrumen evaluasi kognitif, 2) lembar kerja peserta didik (LKPD). Tes kognitif menggunkan game aplikasi quizziz. Semua tahapan dilaksanakan dengan moda daring menggunakan googleclassroom, whatsappgroup, googlemeet dan quizziz 3) Penutup, dengan mengisi refleksi.

\section{HASIL DAN PEMBAHASAN}

Penelitian dilakukan mulai minggu ke 3 Oktober 2020. Penelitian dilakukan sebanyak 2 siklus. Siklus 1 dilaksanakan dengan 2 kali tindakan dan siklus 1 dilaksanakan dengan 1 kali tindakan. Pada tahap awal ini peniliti pelakukan kegiatan prasiklus. Penelitian ini akan di akhiri setelah $75 \%$ peserta didik mengalami peningkatan dalam prestasi belajar dari keseluruhan peserta didik yang belum mencapai ketuntasan minimal (KKM). KKM pada mata pelajaran sosiologi adalah 70. Jika batas ketuntasan minimal tersebut telah tercapai maka penelitian ini dikatakan berhasil.

Prasiklus dilaksanakan tanggal 12-16 Oktober 2020. Dari kegiatan prasiklus diperoleh data rata-rata kelas adalah 65 dengan rincian 20 anak yang belum tuntas Kriteria Ketuntasan Minimal (KKM) atau sekitar 57\%. Peserta didik yang sudah tuntas KKM sebanyak 15 anak atau 43\%. Adapun sebaran data nilai kelas dapat dilihat dalam grafik di bawah ini.

\section{Gambar 2. Grafik Hasil Belajar Prasilus}

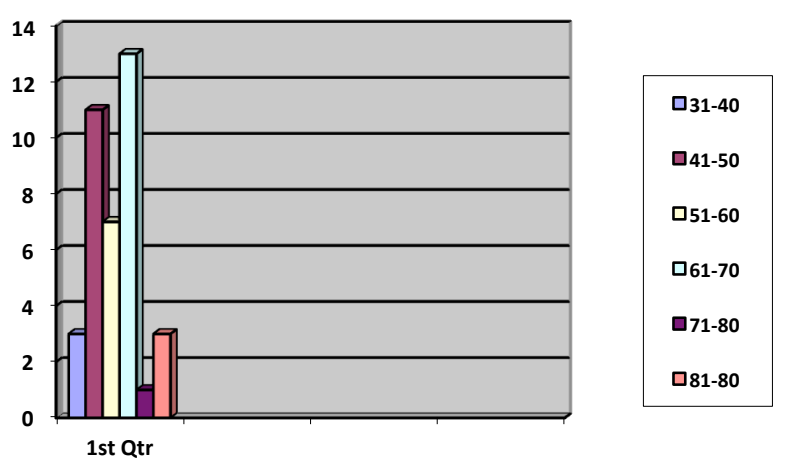

Data dari kegiatan prasiklus hasil belajar sosiologi kelas XI IPS 2 SMA Negeri Purworejo, masih banyak peserta didik yang belum mencapai KKM (Kriteria Ketuntasan Minimal) 70 yaitu 20 peserta didik atau 57\%. Sedangkan peserta didik yang telah mencapai KKM adalah sejumlah 15 anak atau 43\%. Dalam prasiklus ini diperoleh rata-rata nilai kelas 65. Dari data yang diperoleh dalam prasiklus maka perlu diadakan perbaikan dan peningkatan kualitas pembelajaran jarak jauh moda daring di kelas. Maka dari 
itu peneliti mengadakan penelitian tindakan kelas yang bertujuan untuk meningkatkan hasil belajar peserta didik dengan menggunakan model pembelajaran problem solving (pemecahan masalah) dengan berbantuan quizziz sebagai alat evaluasi pengetahuan. Selanjutnya peneliti menyiapkan instrumen yang akan digunakan dalam penelitian antara lain rencana pelaksanaan pembelajaran, bahan ajar, media pembelajaran, dan instrumen penilaian.

Siklus I dilaksanakan dalam dua kali tindakan. Pelaksanaan tindakan 1 pada Rabu 22 Oktober 2020 dan tindakan 2 dilaksanakan pada tanggal 3 november 2020 . Sesuai dengan rencana yang telah dibuat, kegiatan pembelajaran dilaksanakan secara jarak jauh dalam moda daring dengan menggunakan paltform googleclassroom yang dipadukan dengan googlemeet dan quizziz. Metode pembelajaran yang dipilih adalah problem solving. Pembelajaran dengan diawali peneliti membagikan materi secara asinkronus sehari sebelumnya. Kemuadian pada waktu yang telah dijadwalkan peneliti mengawali pembelajaran dengan menggunakan googlemeet. Perbedaan antara tindakan 1 dan tindakan 2 adalah pada proses pengerjaan problem solving dan penulisan hasil akhirnya. Pada tindakan 1 peserta didik bekerja secara individual, sedangkan pada tindakan 2 peserta didik mengerjakan dalam kelompok. Hasil pekerjaan tindakan 1 diwujudkan dalam peta konsep sedangkan pada tindakan 2 diwujudkan dalam power point presentasi yang kemudian dipresentasikan menggunkan googlemeet. Nilai kognitif dalam 2 tindakan ini diambil dalam kegiatan evalusi menggunakan quizzi. Quizziz diberikan di akhir pembelajaran setelah melakukan problem solving. Soal berjumlah 10 dengan durasi pengerjaan adalah 10 menit. Adapun data hasil rata-rata nilai kognitif siklus 1 pada tindakan 1 dan 2 grafik dibawah ini:

\section{Gambar 3. Grafik Rata-rata Hasil Belajar Siklus 1}

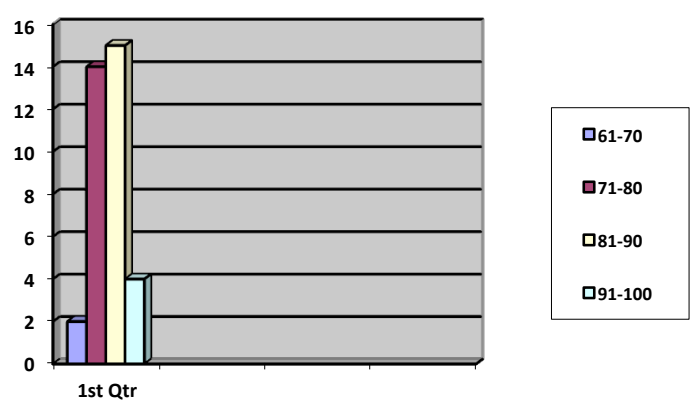

Dari data rata-rata hasil belajar tindakan 1 dan 2 siklus I dapat dijelakan peserta 
didik yang belum tuntas KKM yaitu 2 anak dengan prosentase $6 \%$ dan peserta didik yang telah tuntas KKM yaitu 33 anak dengan prosentase 94\%. Dalam siklus I ini diperoleh rata-rata nilai kelas 81. Jika dibandingkan dengan prasiklus maka sudah ada peningkatan $51 \%$. Setelah melaksanakan siklus 1 tahap selanjutnya adalah refleksi.

Selanjutnya peneliti merancang dan merencanakan pelaksanaaan siklus ke II untuk memperbaiki pembelajaran dari siklus I. Pelaksanaan siklus 2 dilaksanakan dalam satu kali tindakan. Pelaksanaan dilakukan pada Rabu 3 November 2020. Sesuai dengan rencana yang telah dibuat, kegiatan pembelajaran dilaksanakan dengan metode pembelajaran problem solving dengan menggunakan platform googleclasroom yang di padukan dengan whasappgroup, googlemeet dan quizzi. Dalam siklus II ini tindakan ditambah dengan implementasi TPACK dalam proses pembelajaran problem solving. Pada siklus ke II ini metode problem solving dilakukan secara berkelompok dengan. Hal ini bertujuan untuk memberi kesempatan kepada peserta didik untuk berdiskusi. Peserta didik berdiskusi menggunakan whatappgroup kelompok. Pada siklus II ini permasalahan sosial yang diangkat adalah permasalahan sosial terkini dalam masyarakat. Hasil problem solving dibuat dalam infografis dari aplikasi canva. Setelah jadi peserta didi mempresentasikan hasil problem solving di googlemeet. Penilaian kognitif pada siklus II ini masih sama dengan siklus I yaitu menggunakan game edukasi quizziz. Soal berjumlah 10 dengan durasi waktu 15 menit. Dapat dilihat dari grafik hasil belajar di bawah ini.

\section{Gambar 4. Grafik Hasil Belajar Siklus 2}

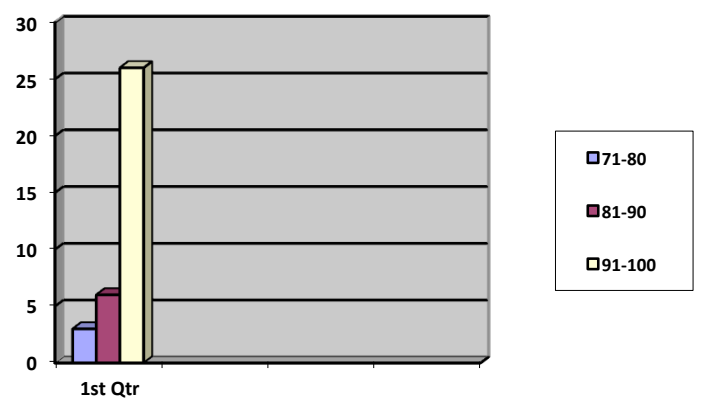

Dari siklus II dapat diperoleh data yaitu semua peserta telah tuntas KKM. Dengan rata-rata 92.

Setelah dilakukan prasiklus, siklus I dan siklus II maka tabel perbandingan prestasi belajar dalam histogram dibawah ini: 


\section{Gambar 5. Histogram Perbandingan Hasil Belajar Peserta Didik Antar Siklus}

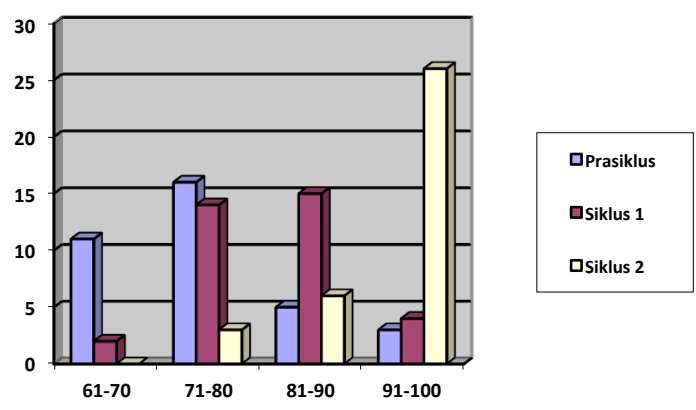

Dari grafik perbandingan di atas dapat diperoleh kesimpulan bahwa rata-rata peningkatan dari prasiklus hingga siklus 2 peningkatan rata-rata kelas 27 point. Dengan prosentase kenaikan peserta didik yang tuntas KKM sebanyak 100\%. Dalam artian dalam siklus 2 tidak ada lagi peserta didik yang nilainya di bawah KKM. Dari analisis data yang diperoleh penerapan model problem solving dengan berbantuan game edukasi quizziz terbukti dapat meningkatkan prestasi belajar peserta didik kelas XI IPS 2 SMA N 7 Purworejo. Dari observasi yang telah dilakukan dan hasil yang telah didapatkan maka dapat disimpulkan oleh peneliti bahwasanya model problem solving dengan berbantuan game edukasi quizziz meningkatkan hasil belajar kognitif peserta didik kelas XI IPS 2 SMA N 7 Purworejo tahun pembelajaran 2020/ 2021.

\section{DISKUSI}

Walaupun pembelajaran dilaksanakan secara jarak jauh moda daring, namun diharapkan pembelajaran ini tidak jauh berbeda dengan pembelajaran secara tatap muka. Permasalahan yang ditemukan dalam PJJ diharapkan dapat diselesaikan dengan inovasi yang dilakukan oleh guru. Salah satu inovasi yang dilakukan adalah dengan merancang pembelajaran yang bermakna dan menarik bagi peserta didik. selain itu pembelajaran juga membekali peserta didik dengan kecakapan abad 21 yaitu kreatif, kolaboratif, komunikatif dan kritis. Pembelajaran sosiologi dengan metode problem solving berbatuan quizzi, adalah salah satu model yang mampu merepresentasikan 4 kecakapan abad 21 seperti di atas. Karena pada metode problem solving ini peserta didik harus melalui tahapan berpikir secara ilmiah yaitu: (1) mengidentifikasi penyebab masalah; (2) mengaji teori untuk mengatasi masalah atau menemukan solusi; (3) memilih dan menetapkan solusi yang paling tepat; (4) menyusun prosedur 
mengatasi masalah berdasarkan teori yang telah dikaji (Endang Mulyatiningsih, 2011:237). Dalam penelitian ini 4 kecakapan diatas dapat dilihat dalam hasil tindakan yaitu peserta didik telah mampu berkolaborasi untuk memecahkan permasalahan dengan kritis, yang dilanjutkan dengan mengkomunikasikan hasil kerja kelompok yang dituangkan dalam berbagai macam teknologi seperti power point, infografis dengan aplikasi online canva. Peserta didik mengkomunikasikan menggunakan vitur presentasi pada pembelajaran sinkronus menggunakan googlemeet. Tindakan diakhiri dengan evaluasi menggunakan game edukatif quizziz. Game quizizz dapat membantu memotivasi belajar peserta didik dan meningkatkan prestasi belajar. Hal ini sejalan dengan pendapat Dewi, C. K. (2018: 43) yang mengatakan bahwa pembelajaran berbasis permainan mempunyai potensi yang baik untuk dijadikan sebagai media pembelajaran yang efektif karena dapat merangsang komponen visual dan verbal.

\section{KESIMPULAN}

Penelitian tindakan kelas yang telah dilaksanakan di kelas XI IPS 2 SMA N 7 Purworejo terdiri dari prasiklus, siklus I dan siklus II. Penerapan model problem solving dengan berbantuan quizziz dapat meningkatkan hasil belajar sosiologi materi permasalahan sosial dalam masyarakat pada peserta didik kelas XI IPS 2 SMA Negeri 7 Purworejo Tahun Pelajaran 2020/2021. Hasil kegiatan pratindakan menunjukkan hasil belajar sosiologi masih banyak yang belum mencapai KKM (Kriteria Ketuntasan Minimal) 70 yaitu 20 peserta didik atau $57 \%$. Sedangkan peserta didik yang telah mencapai KKM adalah sejumlah 15 anak atau 43\%. Dalam prasiklus ini diperoleh rata-rata nilai kelas 65 . Setelah dilakukan refleksi maka dilakukan siklus 1. Dalam penerapan siklus I diperoleh data mencapai KKM yaitu 2 peserta didik dengan prosentase $6 \%$ dan peserta didik yang telah mencapai KKM ada 33 peserta didik dengan prosentase 94\%. Dalam siklus I ini diperoleh rata-rata nilai kelas 81. Setelah dilakukan berbagai refleksi maka dilakukan siklus II dengan hasil 35 peserta didik telah tuntas KKM atau 100\%. Dengan ini dapat disimpulkan 
bahwa metode problem solving dengan berbatuan quizzi dapat meningkatkan hasil belajar sosiologi materi permasalahan sosial pada peserta didik kelas XI IPS 2
SMA Negeri 7 Purworejo pada siklus I dan siklus II mengalami peningkatan yang signifikan.

\section{DAFTAR PUSTAKA}

Dewi, CK., (2018), Pengembangan Alat Evaluasi Menggunakan Aplikasi Kahoot Pada Pembelajaran Matematika Kelas X, UIN Raden Intan Lampung.

Mishra, P., \& Koehler, M., (2006), Technological Pedagogical Content Knowledge: A new framework for teacher knowledge, Teacher College Record, 1017-1054.

Mulyatiningsih, Endang, (2011), Metode Penelitian Terapan Bidang Pendidikan, Yogyakarta, Alfabeta.

Warsito, (2007) Jurnal Teknodik: Peran TIK dalam Penyelenggaraan PJJ No. 20, 9-41, Jakarta, Pustekkom depdiknas. 